\title{
Perilaku Satwa Liar Pada Kelas Burung (Aves)
}

\author{
Rudiansyah $^{1}$, Muhammad Radhi ${ }^{1}$ \\ ${ }^{1}$ Mahasiswa Program Studi Kehutanan. Fakultas Pertanian, Universitas Almuslim, Jalan \\ Almuslim, Matang Glumpang Dua, Peusangan, Kabupaten Bireuen, Aceh 24261 \\ Email: rudiansyahtkn9@gmail.com
}

\begin{abstract}
ABSTRAK
Perilaku satwa liar merupakan gerak gerik satwa liar untuk memenuhi rangsangan dalam tubuhnya dengan memanfaatkan rangsangan yang diperoleh dari lingkungannya. Aves (burung) adalah kelompok hewan bertulang belakang (vertebrata) yang unik, karena sebagian besar aves merupakan binatang yang beradaptasi dengan kehidupan secara sempurna. perilaku makan adalah cara-cara individu dan kelompok individu memilih, mengkonsumsi dan menggunakan makanan-makanan yang tersedia, yang didasarkan kepada faktor-faktor sosial dimana individu tersebut hidup. Perilaku seksual adalah segala perilaku yang muncul karena adanya dorongan seksual atau kegiatan mendapatkan kesenangan organ seksual melalui berbagai perilaku dengan cara merangsang. Perilaku Khas adalah perilaku unik yang hanya dimiliki oleh individu tertentu, yang tidak dimiliki individu lainnya. Perilaku Pergerakan adalah perilaku yang dilakukan untuk mencari makan, berkembangbiak dan melindungi diri dari serangan predator/musuh. Tujuan pengamatan jurnal ini adalah untuk mengetahui perilaku harian burung (AVES) Rongkang, Elang, Kuau Raja, Jalak Bali dan Burung Bayan. Seperti Perilaku Makan, Seksual, Sosial, Khas, dan perilaku Pergerakannya.
\end{abstract}

Kata kunci: Perilaku harian, Burung (Aves), IUCN

\section{PENDAHULUAN}

Perilaku adalah serangkaian tindakan yang dibuat oleh individu, organisme, sistem, atau entitas buatan dalam hubungannya dengan dirinya sendiri atau lingkungannya, yang mencakup sistem atau organisme lain di sekitarnya serta lingkungan fisik (mati). Perilaku satwa liar merupakan gerak gerik satwa liar untuk memenuhi rangsangan dalam tubuhnya dengan memanfaatkan rangsangan yang diperoleh dari lingkungannya. Populasi aves yang termasuk satwa liar memiliki potensi penurunan populasi akibat kehilangan habitat, perburuan, perdagangan liar oleh tingginya harga dan permintaan pasar (Akmal et al., 2019) Ilmu yang mempelajari perilaku satwa disebut etologi. Etologi adalah studi ilmiah dan objektif tentang perilaku hewan, biasanya dengan fokus pada perilaku dalam kondisi alam, dan melihat perilaku sebagai sifat adaptif evolusioner.

Etologi biasaya tertarik pada proses perilaku pada kelompok satwa tertentu dan sering mempelajari satu jenis perilaku, seperti pergerakan, makan, seksual, khas dan sosial. Perilaku juga di pelajari didalam penangkaran untuk dapat mngamati secara langsung. Penangkaran adalah upaya untuk menjaga populasi yang terancam punah (Akmal et al., 2015). Aves (burung) adalah kelompok hewan bertulang belakang (vertebrata) yang unik, karena sebagian besar aves merupakan binatang yang beradaptasi dengan kehidupan secara sempurna. Walaupun semua aves ditutupi bulu, akan tetapi jenis tertentu seperti burung unta, burung emu atau kiwi tidak dapat terbang. Bahkan ada jenis burung tertentu yang tidak memiliki sayap. Aves adalah hewan berdarah panas sama seperti mamalia, aves berkembang biak dengan ovipar (bertelur). Sebagian mereka hidup menetap, dan ada juga yang hidup berpindah tempat (migrasi).

Burung merupakan komponen ekosistem yang memiliki peranan penting dalam mendukung berlangsungnya suatu siklus kehidupan organisme. Keadaan ini dapat dilihat dari rantai makanan dan jaring-jaring kehidupan yang membentuk sistem kehidupannya dengan komponen ekosistem lainnya seperti tumbuhan dan serangga. Manfaat burung antara lain adalah peran ekologisnya yang secara jelas dapat dilihat dan dirasakan langsung. Peran tersebut adalah seperti membantu penyerbukan bunga (burung sesap madu), pemakan hama (burung pemakan serangga atau tikus) dan penyangga ekosistem (terutama jenis burung pemangsa). Fungsi utama burung disuatu lingkungan adalah pengontrol serangga sebagai hama. Saat ini satwa liar memiliki nilai ekonomis yang tinggi sehingga terjadinya perburuan liar semakin meningkat, sehingga dugaan populasi satwa liar berkurang secara dramatis dari tahun ke tahun (Akmal et al., 2014a). Burung juga memiliki nilai ekonomis tinggi yang dapat dimanfaatkan sebagai bahan makanan (daging, telur, sarang), 
diperdagangkan dan dipelihara oleh masyarakat, bulu burung yang indah banyak dimanfaatkan oleh perancang model untuk desain pakaian atau aksesori lainnya(Darmawan, 2012:4).

Perilaku makan adalah cara-cara individu dan kelompok individu memilih, mengkonsumsi dan menggunakan makanan-makanan yang tersedia, yang didasarkan kepada faktor-faktor sosial dimana individu tersebut hidup.

Perilaku seksual adalah segala perilaku yang muncul karena adanya dorongan seksual atau kegiatan mendapatkan kesenangan organ seksual melalui berbagai perilaku dengan cara merangsang. Atau perilaku yang berhubungan dengan fungsi-fungsi reproduktif atau yang merangsang sensasi dalam reseptor-reseptor yang terletak pada atau yang di sekitar organ-organ reproduktif atau daerah-daerah erogen. Informasi tentang status biologi reproduksi satwa liar sangat penting untuk pelaksanaan kegiatan konservasi ex situ. Salah satu aspek dalam biologi reproduksi satwa liar adalah pengetahuan tentang anatomi dan siologi organ reproduksi baik jantan maupun betina (Akmal et al., 2014b). Perilaku seksual adalah segala perilaku yang muncul karena adanya dorongan kegiatan mendapatkan kesenangan organ sexual melalui berbagai perilaku dengan cara merangsang.

Perilaku sosial adalah Perilaku yang dilakukan oleh satu individu atau lebih yang menyebabkan terjadinya interaksi antar individu danantar kelompok.

a. Perilaku Affiliative; adalah perilaku yang dilakukan bertujuan untuk mempererat ikatan sosial, koordinasi antar individu dan kebersamaan antar atau di dalam kelompok

b. Perilaku Agonistic :

$\checkmark$ Perilaku aggressive : perilaku yang bersifat mengancam atau menyerang

$\checkmark$ Perilaku submissive: Perilaku yang menunjukkan ketakutan ataukalah.

c. Vokalisasi; Adalah suara yang dikeluarkan oleh satu atau lebih individu untuk berkomunikasi dan koordinasi diantara anggota kelompoknya

d. Perilaku maternal $/$ mothering; Perilaku induk yang bertujuanmelindungidan memelihara anaknya.

Perilaku Khas adalah perilaku unik yang hanya dimiliki oleh individu tertentu, yang tidak dimiliki individu lainnya.

Perilaku Pergerakan adalah perilaku yang dilakukan untuk mencari makan, berkembangbiak dan melindungi diri dari serangan predator/musuh. Ada dua hal yang menentukan perilaku pergerakan satwaliar, yaitu fungsi primer dan sekunder. Fungsi primer adalah faktor faktor primer yang mendukung satwa untuk bergerak agar kebutuhan fisiologisnya terpenuhi, seperti rasa lapar, haus dan motivasi seksual, oleh karena itu distribusi pakan air dan perkawinan diduga menjadi penentu utama dan penggunaan ruang dapat mencakup sekurang kurangnya variasi mikro-klimat suatu tempat, keadaan medan, resiko bertemu predator atau jenis yang sama dan resiko terkena penyakit.

Tujuan pengamatan jurnal ini adalah untuk mengetahui perilaku harian burung (AVES) Rongkang, Elang, Kuau Raja, Jalak Bali dan Burung Bayan. Seperti Perilaku Makan, Seksual, Sosial, Khas, dan perilaku Pergerakannya.

\section{PEMBAHASAN}

\section{Rangkong}

Burung ini berukuran sangat besar dengan ukuran yang berkisar 110-127 cm. Dalam bahasa inggris, burung rangkong dinamakan - hornbill\| karena paruhnya yang berbentuk seperti tanduk sapi. Rangkong badak memiliki paruh kuning berpangkal merah dengan tanduk berwarna merah-kuning yang melengkung keatas. Bulu didimonasi warna hitam dan putih, sementarakakiberwarnaabu- abu kehijauan dan ekor berwarna putih mencolok dengan garis hitam lebar melintang. Iris berwarna merah untuk rangkong badak jantan dan iris berwarna putih sampai biru untuk rangkong badak betina.

$\begin{array}{ll}\text { Berikutmerupakanklasifikasidariburungrangkong: } \\ \text { Kingdom } & \text { : Animalia } \\ \text { Filum } & \text { : Chordata } \\ \text { Kel } & \text { : Aves } \\ \text { Ordo } & \text { : Coraciiformes } \\ \text { Famili } & \text { : Bucerotidae } \\ \text { Genus } & \text { : Buceros } \\ \text { Spesies } & : \text { Buceros rhinoceros } \\ \text { IUCN } & : \text { Critically Endangered (Kritis) }\end{array}$

\section{a. Perilaku Makan}

Burung rangkong yang hidup di hutan hujan tropis umumnya bersifat frugivorous, tetapi dapat juga bersifat omnivorous saat musim berbiak. Frugivorous adalah hewan pemakan buah. Buah beringin yang berbuah sepanjang tahun di hutan tropis Indonesia merupakan makanan yang sangat penting bagi burung rangkong (Kemp 1995, Hadiprakarsa, 2001). Selain buah beringin, jenis buah- buahan lainnya juga di konsumsi oleh burung rangkong seperti buah pala hutan yang kaya akan protein dan lipid, kenarikenarian. Burung rangkong juga memakan invertebrata dan vertebrata kecil, disaat ketersediaan buah mulai menipis. Saat memakan buah, umumnya rangkong memperlakukan buah dengan dua cara, 
yaitu dengan memasukkan dan melumatkannya di dalam paruh lalu mengeluarkan bijinya dari dalam paruh setelah bagian yang lainnya ditelan. Cara kedua yaitu memasukkan buah (yang umumnya berbiji halus melalui paruh, ke kerongkongan dan terus ke saluran pencernaan di dalam tubuh, lalu bijinya akan dikeluarkan bersama kotorannya (Kemp, 1995).

Sebagai burung pemakan buah, pola makan memperlihatkan aktivitas bimodal, yaitu memulainya pada pagi hari dengan frekuensi tinggi, lalu kemudian menurun pada siang hari dan akan meningkat kembali pada sore hari. Tinggi rendahnya frekuensi aktivitas makan diduga dipengaruhi oleh suhu sekitar dan perubahan intensitas cahaya matahari. Semakin tinggi suhu lingkungan maka semakin besar jumlah makanan yang dikonsumsi untuk memenuhi kebutuhan metabolisme tubuhnya. Pada umumnya burung rangkong lebih memilih makanan yang ada diatas pohon di hutan, jarang dijumpai burung rangkong memakan buahbuahan di atas tanah.

\section{b. Perilaku Seksual}

Ketika saatnya untuk berkembang biak betina akan menemukan sebuah lubang di pohon berongga besar, kanopi yang tinggi untuk meletakkan telurnya. Ketika ia telah menemukan sebuah lubang yang sesuai betina akan menutup diri di dalamnya menggunakan air liur, tanah liat, kotoran dan ranting, dan hanya menyisakan cela kecil yang digunakan untuk mengambil makan dari rangkong jantan atau anggota kelompoknya dengan menggunakan paruh.

Pada saat bersarang Klop (1998) menyatakan bahwa burung jantan akan melakukan terbang secara diam-diam, tidak banyak megepakkan sayap, jika sudah mendekati sarang agar predator tidak mengetahui keberadaannya. Selanjutnya, sebelum jantan memberikan makanan kepada betina, jantan akan melakukan pengintaian di sekitar pohon sarang untuk pengamanan. Fungsi dari menutupi sarang yaitu untuk melindungi betina dan telur dari predator dan gangguan dari jenis rangkong lain (Kinnaird \& O\|Brien 1997).

Poonswad (1993) menyatakan bahwa terdapat lima tahapan proses bersarang pada rangkong selama $120-140$ hari, rerata lama waktu bersarang pada Enggang papan dan Julang emas yaitu sekitar 120 hari, berikut merupakan tahapan dari proses bersarang pada rangkong yaitu :

1. Tahap pre-nesting yaitu periode perkawinan ditunjukkan dengan usaha menemukan sarang (termasuk mengunjungi sarang) sebelum betina terkurung, antara 1-3 minggu.

2. Tahap pre-laying yaitu masa betina mulai terkurung sampai peletakan telur pertama, selama satu minggu. Periode aman bagi rangkong untuk mengeluarkan telurnya(Kemp 1995).

3. Tahap egg incubation yaitu masa peletakkan telur pertama sampai telur pertama menetas, selama enam minggu, sementara pada Kangkareng perut putih selama empat minggu.

4. Tahap nesting yaitu masa dari induk betina keluar dari sarang (lubang sarang ditutup kembali) hingga anak memiliki bulu lengkap dan siap untuk terbang, selama 8-13 minggu.

5. Tahap fledging yaitu masa dari pemecahan plester sampai semua anak keluar, memerlukan waktu dari hitungan beberapa jam hingga dua minggu, jika anak lebih dari satu. Perilaku bersarang pada rangkong merupakan perilaku yang tidak biasa dilakukan pada kelas burung, inilah yang menjadikan rangkong menjadi burung yang istimewa.

\section{c. Perilaku Sosial}

Burung rangkong umumnya hidup berkelompok, baik itu dalam mencari makan atau terbang. Pada saat terbang mereka akan berpasangan dalam sebuah kelompok kecil.

\section{d. Perilaku Pergerakan}

Burung rangkong bersifat arboreal yaitu melakukan aktivitasnya di atas kanopi pohon. Pohon yang digunakan adalah pohon tinggi dengan ketinggian $\geq 30$ meter. Pohon digunakan untuk hinggap, istirahat, tidur dan bersarang. Burung rangkong sebagai spesies kunci mempunyai peranan penting dalam regenerasi hutan karena mempunyai kemampuan menyebarkan benih biji tumbuhan hutan dari buah-buahan yang dimakannya. Burung rangkong sangat dibutuhkan oleh ekosistem karena jangkauan terbangnya yang sangat luas dibanding dengan burung jenis lain (Poonswad 1993; Kinnaird \& O॥Brien 1997; Marthy 2008).

Menurut Kemp (1991) beberapa rangkong hidup menetap bersama pasangannya (monogamous) di dalam wilayah teritorinya (pertahanan), dengan luas jangkauan mulai dari 10 ha sampai $100 \mathrm{~km} 2$. Selanjutnya dijelaskan bahwa jenis rangkong yang hidup di hutan hujan tropis marga (genus) Aceros juga dapat melakukan migrasi menyeberang laut antar pulau sebagai aktivitas hariannya untuk mencari pakan.

Waktu perjumpaan burung rangkong didapatkan hasil pengamatan bahwa pada pagi hari rangkong terlihat beraktivitas terbang melintas jalur berkisar antara pukul 06:00 - 10:00 untuk pergi mencari makan, setelah lewat waktu tersebut burung rangkong akan melakukan aktivitas beristirahat dengan rangkaian kegiatan membersihkan bulu dan bermain dengan pasangannya karena tercatat bahwa rangkong ditemukan selalu berpasangan, tidak pernah 
dalam jumlah ganjil. Pada pukul 16:00 - 18:30 burung rangkong akan terlihat melintas terbang untuk melakukan aktivitas tidur. Namun pada waktu sore hari burung rangkong akan terlihat berkawanan dengan jumlah $3-8$ individu per kelompok.

\section{e. Perilaku Khas}

Burung rangkong dapat dikenali dari suara kepakan sayap pada saat terbang. Suara yang ditimbulkan dari kepakan sayap langsung dapat dikenali (Kinnaird \& O\|Brien 1997). Semua jenis rangkong mempunyai suara yang keras dan terdengar sampai lebih dari satu kilometer (Kinnaird \& O\|Brien 1997). Dijelaskan dalam penelitian Noerfahmy (2008), kelompok Enggang klihingan (Annorhinus galeritus) di TNBBS sering melakukan aktivitas calling. Selanjutnya dijelaskan bahwa calling dilakukan pada waktu-waktu tertentu. Aktivitas ini dilakukan oleh setiap kelompok untuk menandakan keberadaan individu atau kelompok pada suatu lokasi, biasa dilakukan antar individu dalam kelompok atau antar kelompok satu dengan kelompok lain. Calling berfungsi sebagai hal untuk menunjukkan dominasi kelompok. Aktivitas calling dilakukan pada pagi hari dan sore hari menjelang matahari terbenam (Noerfahmy 2008). Pada saat bersarang aktivitas calling rangkong akan berkurang. Klop (1998) menyatakan bahwa jantan akan lebih banyak diam, tidak bersuara jika sudah mendekati sarang, namun jika tidak sedang musim bersarang jantan akan bersuara keras jika merasa terganggu.

\section{Burung Elang}

Elang jawa (Nisaetus bartelsi) burung pemangsa yang dilindungi Peraturan Pemerintah No.7 Tahun 1999 tentang Pengawetan jenis Tumbuhan dan Satwa. Berdasarkan IUCN redlist 2015 versi 3.1 elang jawa termasuk ke dalam status endangered sedangkan berdasarkan CITES tergolong Apendix I. Taman Nasional Alas Purwo (TNAP) salah satu kawasan konservasi memiliki berbagai tipe habitat (hutan payau/mangrove, hutan pantai, hutan alam dataran rendah, padang rumput dan hutan tanaman, namun elang jawa menempati habitat utamanya berupa hutan alam. Elang jawa menggunakan tipe habitat hutan alam dapat memenuhi kebutuhannya sumber pakan berupa satwa arboreal maupun terestrial yang berukuran kecil hingga sedang, maupun pohon mencuat/emergent untuk persarngannya (Afianto 1999; Utami 2002; Widodo 2004).

Informasi dan data mengenai elang jawa di TNAP, baik habitat dan populasinya sangat terbatas, sehingga cukup menarik untuk diteliti. Data dan informasi keberadaan elang jawa di TNAP penting didapatkan untuk mendukung upaya pelestarian pengelolaan elang jawa. Sementara itu gangguan yang paling mengancam bagi burung pemangsa adalah hilang atau rusaknya habitat (Thiollay 1996). Selain itu minat perburuan yang tinggi terhadap burung elang jawa untuk dijadikan peliharaan hidup dan hiasan atau awetan. Berdasarkan keterangan di atas, penelitian ini bertujuan untuk mengidentifikasi dan menganalisis karakteristik habitat elang jawa di TNAP serta perilaku hariannya.

$\begin{array}{ll}\text { Famili } & \text { : Accipitridae } \\ \text { Ordo } & \text { : Accipitriformes } \\ \text { Kingdom } & : \text { Animalia } \\ \text { Kelas } & : \text { Aves } \\ \text { IUCN } & : \text { Endangered (Genting/Terancam) }\end{array}$

\section{a. Perilaku Makan}

Perilaku makan dimulai dengan aktivitas mengawasi mangsa, lalu membungkukkan tubuh dengan pandangan lurus mengamati mangsa, kemudian elang terbang meluncur mencengkram mangsa. Aktivitas berikutnya adalah mencabut bulu mangsa, aktivitas ini sering dilakukan di dasar kandang, karena ukuran diameter tenggeran relatif keciluntukmelakukanaktivitas tersebut.

Elang termasuk hewan homoiotermis, sehingga mampu mempertahankan suhu tubuh tetap stabil tanpa terpengaruh suhu lingkungan. Elang juga merupakan hewan endotermis, yang dapat memproduksi panas tubuh dari kegiatan metabolisme (Indra, 2007). Metabolisme dalam tubuh berperan untuk mempertahankan keseimbangan energi, melalui pengaturan perilaku dan nafsu makan (Meutia, 2005).

Pada dasarnya, seluruh aktivitas makhluk hidup sangat dipengaruhi oleh makanan, karena fungsi makanan sebagai bahan bakar untuk proses metabolisme (Putry, 2011). Perilaku makan elang dipengaruhi oleh hormon ghrelin dari lambung, yang menuju ke hipotalamus posterior (sebagai pusat makan) melalui sirkulasi darah, untuk merangsang NPY (Neuropeptida Y) dan AgRP (Agouti-releated Protein), sehingga menyebabkan lapar. Hormon ghrelin adalah peptida neuroenterik perangsang sinyal lapar, sedangkan NPY dan AgRP adalah neuropeptida sentral yang berperan dalam keseimbangan energi, dengan meningkatkan nafsu makan dan menurunkan pemakaian energi (Meutia, 2005).

Menurut Putry (2011), perbedaan sistem pencernaan aves dengan hewan lain terletak pada bagian mulut dan perut. Elang tidak memiliki gigi untuk memecah makanan secara fisik, sehingga mangsa dicabik terlebih dahulu menjadi bagian yang lebih kecil sebelum ditelan. Burung pemangsa pada umumnya mempunyai usus relatif pendek dan sederhana, sehingga proses pencernaan berlangsung cepat ( \pm empat jam). 


\section{b. Perilaku Seksual}

Perilaku seksual mulai terlihat pada masa awal pembuatan sarang. Pasangan elang biasanya memulai dengan terbang bersama selama beberapa menit kemudian mereka hinggap pada suatu dahan di pohon sarang atau pada pohon lain yang dekat dengan pohon sarang. Selanjutnya betina akan merundukkan tubuhnya hingga posisi hampir mendatar dengan sayap terbuka sambil mengepakkan. Kemudian individu jantan akan menaiki dari belakang dengan sayap terbuka. Setelah kawin elang jantan akan bertengger sebentar lalu terbang (Prawiradilaga 1999).

\section{c. Perilaku Sosial}

Perilaku sosial pada umumnya dijumpai pada satwa liar, terutama dalam upaya untuk Memanfaatkan sumberdaya di habitatnya, mengenali tanda-tanda bahaya, dan melepaskan diri dari serangan pemangsa. Perilaku sosial ini berkembang sesuai dengan adanya perkembangan dari proses belajar mereka.

Ada beberapa hubungan sosial sebagai pola perilaku, yaitu : Hubungan ketergantungan pemeliharaan: hubungan ini biasanya terjadi antara induk dengan anak-anaknya.

1. Hubungan saling menguntungkan

2. Hubungan dominansi-subordinasi: jenis satwa liar dominan pada umumnya adalah satwa liar yang berumur lebih tua, dan individu-individu yang lebih besar. Mereka pada suatu saat akan diganti dengan satu individu dari subordinatnya.

3. Hubungan seksual: hubungan dilakukan oleh satwa liar jantan dan betina dewasa.

4. Hubungan pemimpin dan pengikut

5. Hubungan kerjasama dalam mendapatkan makanan (Alikodra 2002).

Salah satu perilaku sosial yang dilakukan dengan individu lain adalah berupa pertahanan terhadap teritorinya. Perilaku ini biasanya dilakukan pada musim kawin, dimana saat itu elang biasanya lebih agresif. Mereka mempunyai perilaku mempertahankan teritori di sekitar sarangnya. Setiap individu lain baik elang yang sejenis maupun berbeda jenis yang diduga akan membahayakan sarangnya akan diusir oleh pasangan pemilik sarang.

\section{d. Perilaku Pergerakan}

Perilaku bergerak yang sering dilakukan oleh burung elang adalah terbang $(18,46 \%)$, mendatangi pakan $(13,20 \%)$, dan berjalan (10,39\%)). Perilaku bergerak lebih banyak dilakukan oleh jenis burung elang hitam (I. malayensis) dan burung elang paria (M. migrans), karena kedua jenis elang tersebut sangat aktif. Kondisi ini sesuai dengan keadaan burung ini di habitat alamnya yang lebih banyak terbang sepanjang hari, baik mencari pakan maupun gliding atau terbang mengikuti arah angin.

Burung lebih suka berjalan di tanah dan terbang membawa pakannya naik ke atas tenggeran. Beberapa jenis burung mempunyai variasi bentuk dan ukuran kaki, dimana ada jenis burung yang jarang mendarat karena mempunyai kaki yang llemah sehingga sulit atau bahkan tidak bisa digunakan untuk berjalan (Burnie, 1992). Burung pemangsa memiliki kaki yang dilengkapi dengan cakar yang panjang untuk dapat menangkap mangsa sehingga sulit digunakan untuk berjalan. Mangsa yang diperoleh selalu dibawa ke atas tenggeran untuk kemudian dicabik dan dimakan, berbeda dengan burung elang ular bido ( $\mathrm{S}$. cheela) yang lebih menyukai melakukan aktivitas makan di lantai, karena sangat sensitif terhadap gangguan. Apabila dirasa ada gangguan, burung elang ular bido (S. cheela) langsung mengeluarkan suara dan memekarkan bulunya sehingga bentuk badannya terlihat lebih besar. Penglihatan dan pendengarannya sangat berperan penting dan lebih sensitif dibandingkan dengan indera penciuman. Burnie (1992) mengatakan, mata dari burung pemburu atau pemangsa selalu mengarah lurus ke depan memberi pandangan binokuler. Pandangan yang binokuler memungkinkan burung pemangsa melihat mangsa yang mendekat. Burung yang di dalam kandang penangkaran mempunyai kemampuan terbang yang terbatas karena luasan kandang yang terbatas, sehingga tidak memungkinkan bagi seekor burung melakukan aktivitas terbang dalam waktu yang lama. Umumnya burung yang sudah lama di penangkaran, frekuensi dari sifat terbang dan agresifnya akan berkurang dibandingkan dengan burung yang hidup di alam, padahal burung sudah dirancang sedemikian rupa untuk bisa terbang dan ketika terbang burung membutuhkan tenaga yang besar. Kemampuan terbang pada burung dapat memungkinkannya untuk menjelajahi daerah yangluas saat mencarimakanan.

Kemampuan terbang juga dapat menjadikan burung sebagai pemakan yang efektif, oleh karena itu bagi burung yang akan dilepasliarkan harus terlebih dahulu diadaptasikan terhadap keadaan alam dan direhabilitasi kesehatan dan perilakunya dengan lingkungan yang lebih besar agar mampu bertahan hidup pada lingkungan yang baru.

\section{e. Perilaku Khas}

1. Merupakan hewan berdarah panas, mempunyai sayap dan tubuh yang diselubungi bulupelepah.

2. Berkembang biak dengan cara bertelur yang mempunyai cangkang keras di dalam sarang yang dibuatnya. Ia menjaga anaknya sampai mampu terbang.

3. Merupakan hewan pemangsa, makanan utamanya hewan mamalia kecil seperti tikus, tupai dan 
ayam. Terdapat sebagian elang yang menangkap ikan sebagai makanan utama mereka (biasanya elang tersebut tinggal di wilayah perairan).

4. Paruh elang tidak bergigi tetapi melengkung dan kuat untuk mengoyak dagingmangsanya.

5. Mempunyai sepasang kaki yang kuat dan kuku yang tajam dan melengkung untuk mencengkeram mangsa serta daya penglihatan yang tajam untuk memburu mangsa dari jarak jauh tak terkira.

6. Elang mempunyai sistem pernapasan yang baik dan mampu untuk membekali jumlah oksigen yang banyak yang diperlukan ketika terbang.

\section{Kuau Raja (Argusianus argus)}

Kuau Raja (Argusianus argus) adalah salah satu burung yang terdapat di dalam suku Phasianidae. Carolus Linnaeus (1707-1778), ilmuwan Swedia peletak dasar tatanama biologi, memberikan nama ilmiah khusus untuk kuau raja, yakni Argusianus argus. Dalam mitologi Yunani maknanya adalah raksasa bermata seratus dan dalam Bahasa Inggris disebut Great Argus. Kuau raja memiliki bobot hingga 10 kilogram. Selain. dari ukurannya yang besar. Selain ukuran raksasanya serta bulatan-bulan menyerupai mata pada bulunya, ciri khas lainnya adalah terdapatnya dua helai bulu ekor yang panjangnya hingga satu meter. Kuau Raja mempunyai bulu berwarna coklat kemerahan dan kulit kepala berwarna biru. Burung jantan dewasa berukuran sangat besar, panjangnya dapat mencapai $200 \mathrm{~cm}$. Di atas kepalanya terdapat jambul dan bulu tengkuk berwarna kehitaman. Burung jantan dewasa juga memiliki bulu sayap dan ekor yang sangat panjang, dihiasi dengan bintik-bintik besar menyerupai mata serangga atau oceli. Burung betina berukuran lebih kecil dari burung jantan, panjangnya sekitar $75 \mathrm{~cm}$, dengan jambul kepala berwarna kecoklatan. Bulu ekor dan sayap betina tidak sepanjang burung jantan, dan hanya dihiasi dengan sedikit oceli. Di Indonesia, kuau raja hanya ada di Sumatera dan Kalimantan. Secara global, persebarannya ada di Thailand, Myanmar, Malaysia, dan Brunei Darussalam. Habitat yang disukainya adalah hutan primer di dataran rendah hingga ketinggian 1.500 meter diatas permukaan laut.

Dalam status konservasi yang dikeluarkan oleh IUCN Redlist, status kuau raja adalah Near Threatened (mendekati terancam punah). Burung kuau raja juga tercantum dalam Apendiks II CITES. Burung ini ditetapkan sebagai maskot (fauna identitas) provinsi Sumatera Barat lewat Kepmendagri Nomor 48 Tahun 1989, pun tertera sebagai burung yang dilindungi berdasarkan PP No. 7 Tahun 1999. Hidup kuau raja saat ini menghadapi ancaman ganda yaitu diburu untuk diambil bulu dan dagingnya ataupun diperdagangkan serta habitat hidupnya rusak akibat terdegradasinya hutan dan alih fungsi lahan.

$\begin{array}{ll}\text { Genus } & \text { : Argusianus } \\ \text { Kingdom } & \text { : Animalia } \\ \text { Spesies } & : \text { A. argus } \\ \text { Ordo } & : \text { Galliformes } \\ \text { IUCN } & : \text { Near Threatened (Hampir } \\ & \text { Terancam) }\end{array}$

\section{a. Perilaku Makan}

Dalam mencari makanannya kuau raja lebih sering beraktivitas di atas tanah.Kuau raja termasuk satwa pemakan segala (omnivora).Makanan kuau raja yaitu terdiri dari buah-buahan yang jatuh, biji-bijian, siput, semut, dan berbagai jenis serangga.

\section{b. Perilaku Seksual}

Pada musim berbiak, burung jantan memamerkan bulu sayap dan ekornya di depan burung betina. Bulu-bulu sayapnya dibuka membentuk kipas, memamerkan "ratusan mata" di depan pasangannya. Kuau raja termasuk satwa penganut poligini (satu jantan banyak betina).Kebiasaannya adalah membuat sarang di permukaan tanah.

\section{c. Perilaku Sosial}

Kuau raja jantan biasanya soliter dan sangat teritorial.Jantan menunjukkan teritorinya dengan membersihkan daerahnya dari daun, ranting, semak atau batu, dan bersuara di areanya pada pagi hari.Begitu pula dengan kuau raja betina yang memiliki kebiasaan tidak terlalu soliter dan territorial.

\section{d. Perilaku Pergerakan}

Kuau raja memang tidak bisa terbang jauh, namun kekurangan ini diimbanginya dengan kemampuan berlarinya yang sangat baik.Burung ini juga dapat berpindah tempat dengan melompat ke dahan-dahan pohon. Kuau raja juga memiliki penciuman dan pendengaran yang sangat tajam sehinggasukarditangkap.

\section{e. Perilaku Khas}

Suaranya yang meledak-ledak merupakan ciri khas dari kuau raja. Kuau raja mengeluarkan nada ganda dengan bunyi: "ku-wau". Mungkin, itulah salah satu sebabnya mengapa spesies ini diberi nama kuau raja. Suara ini akan terdengar kembali setiap jeda 15-30 detik atau bahkan lebih panjang.

\section{Jalak Bali (Leucopsar rothschildi)}

Jalak Bali (Leucopsar rothschildi) adalah sejenis burung pengicau berukuran sedang, dengan panjang lebih kurang $25 \mathrm{~cm}$, dari suku Sturnidae.Ia turut dikenali sebagai Curik Ketimbang Jalak. Endemik Indonesia, Jalak Bali hanya ditemukan di hutan bagian barat Pulau Bali.Burung ini juga merupakan satu-satunya spesies endemik Bali dan pada 
tahun1991dinobatkan sebagai lambang fauna Provinsi Bali. Keberadaanhewan endemikini dilindungiundang-undang.

Jalak Bali ditemukan pertama kali pada tahun 1910.Nama ilmiah Jalak Bali dinamakan menurut pakar hewan berkebangsa- an Inggris, Walter Rothschild, sebagai orang pertama yang mendeskripsikan spesies ini ke dunia pengetahuan pada tahun 1912.Karena penampilannya yang indah dan elok, jalak Bali menjadi salah satu burung yang paling diminati oleh para kolektor dan pemelihara burung.Penangkapan liar, hilangnya habitat hutan, serta daerah burung ini ditemukan sangat terbatas menyebabkan populasi burung ini cepat menyusut dan terancam punah dalam waktu singkat.Untuk mencegah hal ini sampai terjadi, sebagian besar kebun binatang di seluruh dunia menjalankan program penangkaran jalak Bali. Jalak Bali dinilai statusnya sebagai kritis di dalam IUCN Red List serta di daftarkan dalam CITES Appendix I.

- Kerajaan : Animalia.

- Filum : Chordata.

- Kelas : Aves.

- Bangsa : Passeriformes.

- Famili : Sturnidae.

- Genus : Leucopsar.

- Jenis : Leucopsar rotschildi Steresemann, 1912.

- IUCN : Critically Endangered (Kritis)

\section{a. Perilaku Makan}

Jalak bali biasanya mencari makan dengan cara membongkar atau menggali tanah gembur dengan menggunakan paruhnya. Tujuannya adalah untuk menangkap serangga, larva serangga, dan juga menangkap cacing. Burung Jalak bali ini juga mencari makanan pada permukaan tanah yang ada di padang rumput.Pada saat mencari makan, burung jalak bali pada umumnya berkelompok. Sebab, pada waktu hujan lebat, burung jalak bali suka nekat guna mencari makan. Dalam keadaan seperti ini, banyak sekali kawanan jalak bali yang gampang untuk ditangkap karena badannya basah dengan air hujan dan susah untukterbang.

\section{b. Perilaku Seksual}

Pada habitat alaminya jalak bali termasuk jenis burung yang suka terbang secara berombongan, pada musim kawin yang berlangsung antara bulan September-Desember mereka terbang secara berpasangan sambil mencari makan. Satwa ini membuat sarang di dalam lubang-lubang pohon pada ketinggian 2,5-7 $\mathrm{m}$ daritanah. Jalak Bali merupakan burung yang setia, sehingga dia akan memilih satu pasangan seumur hidupnya. Apabila pasangannya mati maka dia baru akan mencari pasangan baru sehingga perbandingan jantan dan betina (sex ratio) saat melakukan reproduksi adalah 1:1. Ukuran tubuh jantan umumnya lebih besar dibanding betina. Telur Jalak Bali berbentuk oval berwarna hijau kebiruan dengan diameter terpanjang $3 \mathrm{~cm}$ dan terpendek $2 \mathrm{~cm}$.

\section{c. Perilaku Sosial}

Perilaku sosial jalak bali pada umumnya adalah berkelompok, baik pada saat terbang ataupun pada musim kawin.

\section{d. Perilaku Pergerakan}

Jalak bali mempunyai aktivitas harian yang sama, yaitu setelah mata hari terbit mereka mulai terbang secara berkelompok menuju tempat makan dan minum, dan mereka kembali menuju tempat tidur sebelum matahari terbenam. Kegiatan harian ini akan berhenti sama setelah matahari terbenam. Radius pergerakan hariannya bervariasi dari 3-10 km tergantung pada keadaan lingkungannya. Meskipun di alam jalak bali merupakan burung yang paling liar namun aktivitas yang dilakukannya selalu diiringi komunikasi suara antar pasangan-pasangan yang ada. Jalak bali merupakan burung yang menyukai kebersihan. Satwa ini suka bermain air untuk membersihkan badannya. Setelah itu, mereka mengeringkan tubuhnya dengan cara mengigit-gigit bulunya satu persatu. Pengeringan bulu ini dilakukan dengan berjemur sinar matahari dan bertengger di ranting-ranting pohon. Bulu-bulunya akan mengering dan kembali mengkilap bahkan semakin bercahaya.

\section{e. Perilaku Khas}

Jalak Bali punya ciri-ciri yang khusus antara lain mempunyai bulu yang putih pada seluruh tubuhnya. Selain pada ujung ekor serta bagian sayapnya yang memiliki warna hitam. Burung jalak bali ini punya ciri yang khas yaitu pipinya tak ada bulunya. Burung jantan dan burung betina tampak mirip. Suara dari burung Jalak Bali yang khas dengan pekik yang melengking dan juga campuran siul dengan jeda beberapa saat yang kadang-kadang berirama.

Jalak Bali hanya dijumpai di hutan pada bagian barat pulau Bali.Burung ini juga termasuk satusatunya species endemik Bali.Yang mana pada saat tahun 1991 ditetapkan sebagai lambang fauna di provinsi Bali.Terdapatnya hewan endemik ini telah dilindungi olehundang-undang.

\section{Burung Bayan}

Nuri bayan atau Bayan (Eclectus roratus) adalah burung berukuran sedang, dengan panjang sekitar $43 \mathrm{~cm}$, dari salah satu genus burung paruhbengkok Eclectus. Burung ini sangat berbeda dengan burung paruh-bengkok lainnya. Pada awalnya, ahli burung di Eropa mengira Nuri bayan jantan dan betina adalah dua spesies yang berbeda. Ini disebabkan karena perbedaan warna bulu yang mencolok antara jantan dan betina.

Ciri-ciri Nuri bayan jantan memiliki bulu hijau, 
bawah sayap dan sisi dada berwarna merah dan biru, dan kaki berwarna abu-abu kehitaman. Paruh atas berwarna jingga kemerahan dengan ujung kuning, paruh bagian bawah berwarna hitam. Burung betina memiliki bulu merah, dada dan punggung biru keunguan, dan paruh berwarna hitam. Umumnya, betina berukuran lebih kecil dari jantan.

Makanan burung ini adalah aneka buah-buahan, kacang, dan biji-bijian. Burung ini bersarang di dalam lubang pohon. Betina biasanya menetaskan dua butir telur berwarna putih.

$\begin{array}{ll}\text { Spesies } & : \text { E. Roratus } \\ \text { Kingdom } & : \text { Animalia } \\ \text { Ordo } & : \text { Psittaciformes } \\ \text { Genus } & : \text { Eclectus; Wagler, } 1832 \\ \text { Kel } & : \text { Aves }\end{array}$

Family: Cacatuidae (kakatua)

IUCN : Dilindungi

\section{a. Perilaku Makan}

Perilaku makan tertinggi pada jantan terjadi saat memelihara anak $(26,8 \%)$ dan yang terendah pada saat kawin (10,5\%). Sedangkan pada betina perilaku makan tertinggi juga terjadi pada saat me- melihara anak (16,8\%) dan terendah juga pada saat masa kawin $(6,8 \%)$. Pakan yang biasa diambil ter- lebih dahulu oleh bayan adalah biji matahari atau telur puyuh. Pada allofeeding biasanya betina menunjukkan perilaku untuk meminta makan dengan membungkukkan badan, merendahkan kepala, mengibaskan bulu, atau vokalisasi (Siebert 2006). Perilaku makan pada burung bayan, jika pa- kan tersebut tidak bisa dipegang oleh kakinya (jagung, biji matahari, telur puyuh, tauge, kangkung, dan jambu biji), ia akan makan di tempat pakannya. Akan tetapi, jika pakan tersebut besar dan bisa di- pegang oleh kakinya (wortel, kedondong, kacang panjang, kelapa, dan roti), ia akan makan di tempat pakannya atau membawa pakan tersebut ke tempat dimana ia biasa bertengger dan memakan pakan tersebut. Perilaku allofeeding yang dilakukan betina di kandang sama dengan yang dilakukan di alam, yaitu dengan vokalisasi terlebih dahulu sebagai tanda kepada jantan, lalu mulai mengeluarkan kepal- anya dari sarang. Saat jantan sudah mendekat, paruh betina pun mulai mendekat kepada paruh jantan hingga akhirnya jantan melakukan regurgitasi.

\section{b. Perilaku Seksual}

Perilaku seksual, dibedakan antara bercumbu dan kawin. Perilaku bercumbu dan kawin memiliki angka yang sama antara jantan dan betina. Perilaku bercumbu tertinggi terjadi pada masa kawin $(1,7 \%)$ dan terendah pada masa mengeram yaitu $(0,3 \%)$. Sedangkan perilaku kawin tertinggi terjadi pada masa kawin $(0,6 \%)$ dan tidak terjadi perilaku kawin pada masa mengeram dan memelihara anak $(0 \%)$. Perilaku bercumbu pada bayan biasanya berupa per- ilaku betina yang menggesek-gesekkan bagian atas kepalanya ke leher jantan, atau sebaliknya. Atau berupa paruh yang saling berdekatan atau saling beradu. Selama pengamatan berlangsung, perilaku kawin rata-rata berlangsung selama 4-5 menit, ditandai dengan posisi jantan yang berada di atas betina. Perilaku ini tidak terjadi selama masa mengeram dan memelihara anak.

\section{Kesimpulan}

Kesimpulan yang dapat diambil dari pembahasan diatas adalah Setiap satwa memiliki karakteristik perilaku (makan, seksual, sosial, pergerakan, dan perilaku khas) yang berbeda. Hal ini disebabkan karena faktor internal dan juga eksternal. Faktor internal yang mempengaruhi perilaku satwa meliputi genetik, morfologi, psikologi dan physiologi. Sedangkan faktor eksternal meliputi pengaruh lingkungan disekitar satwa tersebut atau habitat satwa (iklim, predator, pakan, air, ruang gerak, dan sosial).

\section{DAFTAR PUSTAKA}

Afianto MY. 1999. Studi Aspek Ekologi Elang Jawa (Spizaetus Bartelsi Stresemann 1924) Di Gunung Salak [Skripsi]. Bogor (ID): Institut Pertania. Bogor.

Akmal, Y., Nisa, C., \& Novelina, S. (2014a). Anatomi Organ Reproduksi Jantan Trenggiling (Manis javanica). Acta Veterinaria Indonesiana, 2(2), 74-81.

Akmal, Y., Nisa, C., \& Novelina, S. (2014b). Anatomy of the Male Reproductive Organs of Javan Pangolin (Manis javanica). In Proceeding the 3 Joint International Meeting Bogor Indonesia P-03: 1 (Vol. 2). Hal: 69-70.

Akmal, Y., Muliari, Nisa, C., \& Novelina, S. (2015). Anatomy Accessory Glands Of Male Reproductive Of Javan Pangolin (Manis javanica). In Proceeding the 1th Almuslim International Conference on Science, Technology and Society (AICSTS), 1(1) Hal: 192-197.

Akmal, Y., Nisa, C., \& Novelina, S. (2019). Morfologi Kelenjar Aksesori Kelamin Jantan pada Trenggiling (Manis javanica) (Morphology Of The Male Sex Accessory Glands Of The Pangolin (Manis javanica)). Jurnal Veteriner, 20(36), 38-47. https://doi.org/10.19087/jveteriner.2019.20.1.3 8

Darmawan, M.P. 2006. Keanekaragaman Jenis Burung Pada Beberapa Tipe Habitat Di Hutan Lindung Gunung Lumut Kalimantan Timur. Skripsi. Devartement konservasi Sumberdaya hutan dan ekowisata fakultas Kehutanan Institut pertanian bogor. Bogor.

Dirgayusa, I. W. 1995. Jalak Bali Leucopsar rothschildi Stresemann:Tinjauan Status, 
Pengetahuan dan Konservasi. Workshop Important Bird Area. Bird Life International Indonesia Programme.

Ferina, R. 2011. Perilaku Harian Kuau Raja (Argusianus argus Linnaeus) di Taman Marga Satwa dan Budaya Kinantan Bukittinggi Sumatera Barat. Skripsi. Universitas Andalas. Padang.

Heinsohn, R., S. Legge. 2003. Breeding biology of the reverse-dichromatic, co-operative parrot Eclectus roratus. Journal of Zoology, 259: 197-208.

MacKinnon, J., Phillipps, K., Van Ballen B. 2010. BurungBurung di Sumatera, Bali, dan Kalimantan. Burung Indonesia. Bogor.

Masllud B. 2010. Teknik Menangkarkan Burung Jalak di Rumah. Bogor: IPB Press.

Rachmatika, R. 2011. Perilaku Harian Dan Konsumsi Pakan Bayan (Eclectus Roratus) Pada Masa Kawin, Mengeram, Dan Memelihara Anak. 20(2): 35-43.

Rafi, M., Novarino, W., Rizaldi., dan Ardiyanto A. 2017. Aktivitas Kuau Raja (Argusianus Argus Linnaeus, 1766) Pada Mating Ring Di Hutan Konservasi Kalaweit Supayang, Solok, Sumatera Barat. JURNAL METAMORFOS.

SITORUS, D. N., dan HERNOWO, J. B. 2016. Habitat Dan Perilaku Elang Jawa (Nisaetus bartelsi) Di Sptn 1 Tegaldlimo Taman Nasional Alas Purwo, Jawa Timur. Media Konservasi. 21: 278-285.

TARIGAN, S.BR., dan HERNOWO, J. B. 2016. Habitat Dan Perilaku Kangkareng Perut-Putih(Anthracoceros albirostris convexus Temm. 1832) Di Resort Rowobendo Tn Alas Purwo. Media Konservasi. 21: 199-206.

WINARNO, G. D., dan HARIANTO, S. P. (2013). Perilaku Satwa Liar (Ethology). CV.Anugrah Utama Raharja (AURA). Bandar Lampung.

Zulfikri. 2013. Sebaran dan Pola Perilaku Kuau Raja (Argusianus argus) di Stasiun Penelitian Way Canguk, Taman Nasional Bukit Barisan Selatan (TNBBS). Skripsi. Bogor. Institut Pertanian Bogor 
